\title{
An unusual cause of small bowel perforation: apricot pit
}

\author{
Nadir bir ince bağırsak delinme nedeni: Kayısı çekirdeği
}

\author{
Koray ATILA, Sanem GÜLER, Seymen BORA, Hüseyin GÜLAY
}

\begin{abstract}
Ingestion of foreign bodies can be a common problem, especially among children, alcoholics, and psychiatric and senile patients. Foreign bodies with smooth edges usually do not pose significant problems, but a sharp foreign object that is not retrieved immediately may penetrate the wall and cause complications. Ingested foreign bodies usually pass the intestinal tract uneventfully, and perforation occurs in less than $1 \%$. In this study, we report a case of small bowel obstruction with perforation in a 73-year-old female due to the accidental swallowing of an apricot pit.
\end{abstract}

Key Words: Apricot pit; foreign body; small bowel perforation.
Yabancı cisimlerin yutulması, özellikle çocuklar, alkolikler, psikiyatrik hastalar ve yaşlılar arasında yaygın bir sorundur. Yuvarlak uçlu yabancı cisimler sıklıkla bir soruna neden olmazken sivri uçlu yabancı cisimler erken dönemde çıkarılmadıkları takdirde intestinal duvara penetre olup komplikasyona neden olabilirler. Yutulan yabancı cisimlerin çoğunluğu sorunsuz intestinal kanaldan geçerken sadece $\% 1$ 'den daha azı perforasyona neden olur. Bu yazıda, 73 yaşında kadın hastada yanlışlıkla yutulan kayısı çekirdeğine bağlı ince bağırsak tıkanıklığı ve delinmesi olgusunu sunduk.

Anahtar Sözcükler: Kayısı çekirdeği; yabancı cisim; ince bağırsak delinmesi.
Ingestion of foreign bodies can be a common problem, especially among children, alcoholics, and psychiatric and senile patients. Approximately 80\% to $90 \%$ of small foreign bodies reaching the stomach will spontaneously pass through the alimentary canal. ${ }^{[1]}$ It is currently thought that less than $1 \%$ of ingested foreign bodies will perforate the bowel; large, sharp or pointed objects carry the greatest risk. ${ }^{[2]}$ Adhesions due to previous abdominal surgery are the most common cause of small bowel obstruction in adults. Food bolus impaction is one of the rare causes of such an obstruction. ${ }^{[3]}$ Food bolus impaction is common with meat and fish bones, but very few cases due to fruits have been reported. ${ }^{[4]}$

In this study, we report a case of small bowel obstruction with perforation in a 73-year-old female due to the accidental swallowing of an apricot pit.

\section{CASE REPORT}

A 73-year-old female was admitted to the emergency department of our hospital with a three-day history of diffuse abdominal pain, nausea and vomiting. She had vomited her digested daily meal several times and had not passed any gas for two days. She was well before this attack, except for chronic constipation. She had a history of prior abdominal hysterectomy-bilateral salpingo-oophorectomy operation.

Although she had decreased skin turgor and dry mucosal surfaces, there was no sign or symptom of neurologic deficit or psychiatric illness. On physical examination, abdominal distension and accompanying hyperactive bowel sounds on each upper abdominal quadrant were present. She had a low-midline abdominal incision scar, and no inguinal or incisional hernia was seen. There was generalized tenderness on palpa- 


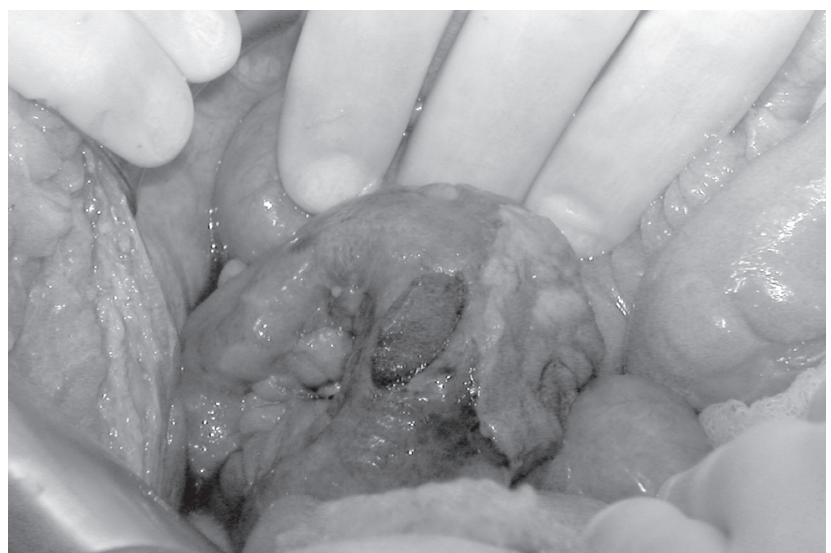

Fig. 1. Appearance of the apricot pit perforating the distal ileum.

tion. No electrolyte imbalance was observed. A plain $\mathrm{X}$-ray of the abdomen revealed multiple air-fluid levels of the small bowel and no free air in subdiaphragmatic areas. Abdominal ultrasonography revealed only dilated loops of intestinal segments, which confirmed the presumptive diagnosis of ileus. On the 24th hour of admission, she developed an "acute abdomen". She underwent an exploratory laparotomy, which revealed a peritoneal soiling due to distal ileum perforation caused by an apricot pit. It was loosely sealed off by an omentum patch (Fig. 1). The peritoneal cavity was irrigated with warm normal saline. Segmental resection of the terminal ileum and end to end anastomosis was performed. A closed wound suction drainage tube was placed in the pelvis. Histologic examination revealed focal mucosal necrosis and foreign body type granular reaction on mucosal, submucosal and muscular layers. Necrotic areas were seen extending to the serosal layer.

On the postoperative 10th day, an enterocutaneous fistula developed. It was treated initially with a combination of total parenteral nutrition and somatostatin, then daily output was followed. Since it was considered a low-output fistula, somatostatin treatment was discontinued within 72 hours. The fistula resolved spontaneously and she was discharged from the hospital on postoperative 24 th day.

\section{DISCUSSION}

Accidental ingestion of a foreign body occurs rarely and perforation occurs in less than $1 \%$ of ingested bodies. ${ }^{[5]}$ The most common sites of intestinal perforation by a foreign body are the ileocecal and rectosigmoid regions. ${ }^{[6]}$ Clinical presentations vary, depending on the site of perforation and the extent and duration of peritonitis. ${ }^{[7]}$ As these patients usually do not remember the foreign body ingestion, the final diagnosis is frequently delayed. Computed tomography scans and ultrasonography may help clinicians in this challeng- ing situation; however, in most patients, the diagnosis is not confirmed until the surgical intervention.

The risk factors for foreign body ingestion are mental retardation, dental prothesis, alcohol abuse, and rapid eating. ${ }^{[5]}$ In our case, the patient had dental plates and rapid eating habit. On questioning, she explained that she had a fruit garden and reported eating a lot of apricots rapidly during the week. Although an apricot pit is not sharp and pointed, it was impacted to the distal ileum region, causing necrosis with perforation. ${ }^{[8]} \mathrm{A}$ myriad of swallowed foreign bodies have been reported. ${ }^{[5-7]}$ Those most commonly associated with complications are toothpicks, fish and chicken bones and needles. ${ }^{[6,8-12]}$ Although most of the sharppointed objects entering the stomach will pass through the remaining gastrointestinal tract without incident, the risk of complication caused by a sharp-pointed object is as high as $35 \% .{ }^{[13]}$ Sharp, pointed foreign bodies often cause perforations in the gastrointestinal tract; endoscopic removal is advisable if they are within the reach of available endoscopes. ${ }^{[14]}$ With advances in endoscopic techniques, foreign bodies can be extracted safely in these patients. The majority of foreign body ingestions occur in the pediatric population, and children most often ingest toys, coins, safety pins, and ballpoint pen caps, ${ }^{[15]}$ whereas adults prevalently tend to have problems with meat and bones. ${ }^{[13]}$ Normal physical examination findings and absence of symptoms in children do not eliminate the possibility of foreign body ingestion especially in the presence of positive history. ${ }^{[15]}$

After 14 days, the fistula of the patient resolved with administration of gastrointestinal decompression, total parenteral nutrition and intravenous somatostatin infusion.

In conclusion, although intestinal obstruction and perforation occur rarely after foreign body ingestion, ${ }^{[5]}$ this situation should always be considered in the differential diagnosis, and early therapeutic precautions should be taken especially in selected patients.

\section{REFERENCES}

1. Eisen GM, Baron TH, Dominitz JA, Faigel DO, Goldstein JL, Johanson JF, et al. Guideline for the management of ingested foreign bodies. Gastrointest Endosc 2002;55:802-6.

2. Selivanov V, Sheldon GF, Cello JP, Crass RA. Management of foreign body ingestion. Ann Surg 1984;199:187-91.

3. Lohn JWG, Austin RCT, Winslet MC. Unusual causes of small bowel obstruction. J R Soc Med 2000;93:365-68.

4. Ihara N, Yashiro N, Kinoshita T, Yoshigi J, Kasai T. Small bowel obstruction due to pickled Japanese apricot: CT findings. J Comput Assist Tomogr 2002;26:132-3.

5. Velitchkov NG, Grigorov GI, Losanoff JE, Kjossev KT. Ingested foreign bodies of the gastrointestinal tract: retrospective analysis of 542 cases. World J Surg 1996;20:1001-5.

6. Pinero Madrona A, Fernández Hernández JA, Carrasco Prats M, Riquelme Riquelme J, Parrila Paricio P. Intestinal perfo- 
ration by foreign bodies. Eur J Surg 2000;166:307-9.

7. Losanoff JE, Kjossev KT. Ingested foreign bodies of the gastrointestinal tract. J Emerg Med 1999;17:525-6.

8. Goh BK, Chow PK, Quah HM, Ong HS, Eu KW, Ooi LL, et al. Perforation of the gastrointestinal tract secondary to ingestion of foreign bodies. World J Surg 2006;30:372-7.

9. Steenvoorde P, Moues CM, Viersma JH. Gastric perforation due to the ingestion of a hollow toothpick: report of a case. Surg Today 2002;32:731-3.

10. Hsu SD, Chan DC, Liu YC. Small-bowel perforation caused by fish bone. World J Gastroenterol 2005;11:1884-5.

11. Nagaraj HS, Sunil I. Multiple foreign body ingestion and il- eal perforation. Pediatr Surg Int 2005;21:718-20.

12. Bhatia R, Deane AJ, Landham P, Schulte KM. An unusual case of bowel perforation due to fish fin ingestion. Int J Clin Pract 2006;60:229-31.

13. Stack LB, Munter DW. Foreign bodies in the gastrointestinal tract. Emerg Med Clin North Am 1996;14:493-521.

14. Webb WA. Management of foreign bodies of the upper gastrointestinal tract: update. Gastrointest Endosc 1995;41:39-51.

15. Yalçin S, Karnak I, Ciftci AO, Senocak ME, Tanyel FC, Büyükpamukçu N. Foreign body ingestion in children: an analysis of pediatric surgical practice. Pediatr Surg Int 2007;23:755-61. 